\title{
Source apportionment using LOTOS-EUROS: module description and evaluation
}

\author{
R. Kranenburg, A. J. Segers, C. Hendriks, and M. Schaap \\ TNO, P.O. Box 80015, 3508 TA, Utrecht, the Netherlands \\ Correspondence to: R. Kranenburg (richard.kranenburg@tno.nl) \\ Received: 30 October 2012 - Published in Geosci. Model Dev. Discuss.: 28 November 2012 \\ Revised: 26 April 2013 - Accepted: 7 May 2013 - Published: 3 June 2013
}

\begin{abstract}
To design effective mitigation strategies, the origin of emissions which produce air pollutants needs to be known. Contributors to air pollutants can be emission sources, like road traffic or industry, but also be more specified to emission from one location or from a specified time. Chemistry transport models can be used to assess the origin of air pollution across a large domain. However, in traditional simulations the information on origin is lost and brute force scenario studies are performed to assess the origin. Alternatively, one can trace the origin of air pollutants throughout a simulation using a labeling approach. In this paper we document and demonstrate a newly developed labeling module for the chemistry transport model LOTOS-EUROS which tracks the source allocation for all particulate matter components and precursor gases. Dedicated simulations confirmed that the new module functions correctly. The new module provides more accurate information about the source contributions than using a brute force approach with scenario runs as the chemical regime remains unchanged. An important advantage of the new module is the reduction of computation costs and analysis work associated with the calculations. The new module was applied to assess the origin of particulate nitrate across the Netherlands. Averaged across the Dutch territory, the main contributions to nitrate are derived from road and non-road transport as well as power plants. Overall, only one-fifth of the concentration derived from sources located inside the country. The new technology enables new research directions as improved information on pollution origin is desired for policy support as well as scientific applications.
\end{abstract}

\section{Introduction}

Exposure to particulate matter (PM) in ambient air leads to human health problems (Dockery et al., 1993; Klemm et al., 2000). Deposition of secondary inorganic aerosol and its precursors leads to a loss of biodiversity through acidification and eutrophication of soils and surface waters (e.g. Bobbink et al., 2010). Moreover, particulate matter components play a key role in climate change affecting the radiation balance of the earth (Forster et al., 2007). To limit the effects of PM pollution, efforts are made to reduce emissions of PM and its precursors. To design cost effective mitigation strategies, a thorough understanding of the sources of particulate matter is crucial. As PM consists of a host of components with different sources and atmospheric behaviour, establishing the origin of PM remains a challenge. Detailed field campaigns that are designed to establish the origin of PM differ in complexity. Composition and tracer data have often been used to interpret PM time series and origin. Chemical mass closure studies are reported for many regions (Putaud et al., 2010). These detailed chemical speciation data sets enable the use of statistical approaches, such as positive matrix factorisation, to identify PM origin (Viana et al., 2009). However, these methods are only able to distinguish between a limited number of broad source categories. Furthermore, they are typically not able to provide a source apportionment for secondary components. Hence, additional data are needed to establish a full source apportionment. Complementary to experimental data, a chemical transport model (CTM) can be used to obtain a more detailed source apportionment. Chemical transport models provide calculations of the evolution of the air pollution situation across a region based on emission inventories and atmospheric process descriptions. 
Hence, they implicitly contain the information to perform a source apportionment. Numerous studies have employed a brute force approach to gain insight in source contributions. In these studies scenario runs are used reducing the emissions of sources under investigation and comparing the differences to the base case (e.g. Lane et al., 2007). Although the computational burden is large, this approach provides a good insight into inert species. However, in case of species involved in atmospheric chemistry, a negative impact on the source apportionment results may occur as perturbing emissions may cause non-linear effects. Presently, few models are equipped with modules to overcome these negative impacts on chemical reactive species. Most divide the PM components into source-specific species that are tracked separately through the model (e.g. McHenry et al., 1992; Ying and Kleeman, 2006). These approaches are capable of accurately tracking the source contribution for secondary species. However, the computational burden remains as large as using a scenario approach limiting their use for a large number of sources. Note, tagging methods have also been developed for ozone by Emmons et al. (2012), Butler et al. (2011), Grewe et al. (2010) and Wang et al. (2009). In these methods the model description is extended with duplicate tracers and chemical reactions. Yarwood et al. (2004) and Wagstrom et al. (2008) present the Particulate Source Apportionment Technology (PSAT) algorithm within CAMx, combining the capability of accurately dealing with secondary species with limited CPU demand. With PSAT the concentration of the species is modelled as before, but next to this the fractional contribution of all sources is kept track of through all processes. CAMx incorporates detailed process descriptions, but requires a large computational time to perform simulations over long time periods. Hence, applications to the full European domain do not exist. We developed a source apportionment model for the operational CTM LOTOS-EUROS (Schaap et al., 2008) to be able to study the origin of particulate matter in Europe in more detail. In this paper we document, validate and demonstrate the new source apportionment module inspired by the PSAT approach. We apply the source apportionment system to study the origin of ammonium nitrate in the Netherlands. Ammonium nitrate is the most important component of particulate matter in the Netherlands (Weijers et al., 2011). In the Netherlands ammonium nitrate levels rise more than proportionally with total PM (Weijers et al., 2011), which has also been observed in other countries (Putaud et al., 2010). We focus on nitrate as it is a product of complex chemistry and its precursor originates from multiple source sectors. The source apportionment for nitrate is part of a larger effort to assess the origin of PM in the Netherlands as reported by Hendriks et al. (2013). In this paper we first present a short overview of the LOTOS-EUROS model (Sect. 2). Second, a detailed description of the labeling source apportionment technique is given (Sect. 3. Next, the results of a technical validation to ensure a proper functioning of the system for the different processes are presented (Sect. 4), with special attention to the chemistry in Sect. 5. Also, the application aimed to establish the origin of nitrate in the Netherlands is shown (Sect. 6). The paper is concluded with a summary of the main results and a short discussion on the benefits of the developed module.

\section{The LOTOS-EUROS chemistry transport model}

The model employed in this study is the 3-D chemistry transport model LOTOS-EUROS, which is aimed at the simulation of air pollution in the lower troposphere. The model is of intermediate complexity in the sense that the relevant processes are parameterized in such a way that the computational demands are modest enabling hour-by-hour calculations over extended periods of several years within acceptable CPU time. The current master domain of LOTOSEUROS is bound at $35^{\circ}$ and $70^{\circ} \mathrm{N}$ and $30^{\circ} \mathrm{W}$ and $60^{\circ} \mathrm{E}$. The model projection is normal longitude-latitude and the standard grid resolution is $0.50^{\circ}$ longitude $\times 0.25^{\circ}$ latitude, approximately $25 \mathrm{~km} \times 25 \mathrm{~km}$. The actual domain for a simulation can be set as long as it falls within the master domain as specified above. In addition, it is possible to increase or decrease the resolution up to factor 4 . In the vertical, the model extend to $3.5 \mathrm{~km}$ above sea level and uses the dynamic mixing layer approach to determine the model vertical structure. This means that on top of a $25 \mathrm{~m}$ surface layer a well-mixed boundary layer is assumed. The height of the mixing layer is obtained from the ECMWF meteorological input data used to drive the model. The height of the reservoir layers is determined by the difference between ceiling $(3.5 \mathrm{~km})$ and mixing layer height. Both layers are equally thick with a minimum of $50 \mathrm{~m}$. In a few cases, when the mixing layer extends near or above $3500 \mathrm{~m}$, the top of the model exceeds the $3500 \mathrm{~m}$ according to the above-mentioned description. The advection in all directions is handled with a monotonic advection scheme (Walcek and Aleksic, 1998). Gas phase chemistry is described using the TNO CBM-IV scheme, which is a condensed version of the original scheme (Whitten et al., 1980). Hydrolysis of $\mathrm{N}_{2} \mathrm{O}_{5}$ is described explicitly (Schaap et al., 2004). Cloud chemistry is described following Banzhaf et al. (2011). Aerosol chemistry is represented using ISORROPIA2 (Nenes et al., 1998). The dry deposition in LOTOSEUROS is parameterized following the well-known resistance approach following the EDACS system (Erisman et al., 1994), including a compensation point approach for ammonia (Wichink Kruit et al., 2012). The aerodynamic resistance is calculated for all land use types separately. Below cloud scavenging is described using simple scavenging coefficients for gases (Schaap et al., 2004) and particles (Simpson et al., 2003).

Anthropogenic emissions are prescribed using the TNOMACC emission inventory (Kuenen et al., 2011). The temporal variation of the emissions is represented by time factors. For each source category a monthly factor breaks down the 
annual total into monthly totals. This value is multiplied by a factor for the day of the week (i.e. Monday, Tuesday, etc.) and finally with a factor for the hour of the day (local time). The LOTOS-EUROS model includes a biogenic emission routine based on detailed information on tree species over Europe (Koeble and Seufert, 2001). The emission algorithm is described in Schaap et al. (2009) and is very similar to the simultaneously developed routine by Steinbrecher et al. (2009). Sea salt emissions are described using Måertensson et al. (2003) and Monahan et al. (1986) for the fine mode and coarse mode, respectively.

The LOTOS-EUROS model has participated in several international model intercomparison studies addressing ozone (Hass et al., 1997; Van Loon et al., 2007; Solazzo et al., 2012a) and particulate matter (Cuvelier et al., 2007; Hass et al., 2003; Stern et al., 2008; Solazzo et al., 2012b) and shows comparable performance to other European models. The LOTOS-EUROS model shows a systematic underestimation of PM of about $40 \%$. This is mainly due to the missing process descriptions for secondary organic aerosols in the model. For the secondary inorganic aerosols the model shows a much smaller underestimation, while the temporal correlation is about 0.6 to 0.8 .

\section{Source apportionment module}

\subsection{Overview}

To track the origin of the modelled concentrations for different tracers, a source apportionment module for the LOTOSEUROS was developed. The method is developed for the LOTOS-EUROS version 1.8 and can be generally used in later versions. Using a labeling technique the new modules calculate the contribution of specified sources for all model grid cells and time steps. In this calculation the contributions per label are calculated as fractions of the total tracer concentration. As the fractions must add up to one for mass conservation, all processes that are sources and sinks of mass within the model must be accounted for in the source apportionment module, including initial and boundary conditions. The calculations to track the source contributions differ per process; the processes in the model can be categorized in four groups:

- Emissions

- Anthropogenic emissions

- Natural emissions

- Transport processes

- Advection

- Diffusion

- Adjustment

- Sedimentation
- Removal processes

- Dry deposition

- Wet deposition

- Chemistry

- Gas phase chemistry

- Aerosol chemistry

For each of these processes the calculations are described below.

\subsection{Emissions}

The specification of the labels to track throughout the model simulations is done in the emission routine. In principle, the definition of the labels is very flexible and any kind of allocation is possible as long as the required detail is present in the input data. For example, emissions from road transport, from a specific country during daylight can be labelled. As one is mainly interested in the source contribution of the anthropogenic sources, the natural emissions (sea salt, biogenic non-methane volatile organic compounds (NMVOC) and windblown dust) are treated separately and obtain a separate label. In the current application and system environments, the number of labels is restricted to 35 . With this amount of labels, the runtime and the output will still be feasible.

For each hour in the simulations the base emission data containing the annual average emission per sector and country for each grid cell is processed and added into the emission array using the sector dependent time profiles. During this processing the source contributions are also accounted for in the array $f r_{\mathrm{emis}}(l)$. This array contains the emission of each source of interest (labelled by $l$ ) as a fraction of the total emission. During each time step $n$, the concentration changes due to all emissions $\left(c_{\mathrm{f}}\right)$ are added to the existing concentrations $c_{n-1}$ and the new source allocation $f r_{n}(l)$ is updated by a straight forward weighted average of existing and concentration change:

$\boldsymbol{f} \boldsymbol{r}_{n}(l)=\frac{\boldsymbol{f} \boldsymbol{r}_{n-1}(l) \cdot c_{n-1}+\boldsymbol{f} \boldsymbol{r}_{\mathrm{emis}}(l) \cdot c_{\mathrm{f}}}{c_{n}}$.

In the equation above $f r_{n}(l)$ and $f r_{n-1}(l)$ are the new and the old fractions for label $l$. The total old and new concentrations are given by $c_{n-1}$ and $c_{n}$, while the emitted mass flux converted to a concentration change is given by $c_{\mathrm{f}}$. In the model, concentrations are in volume mixing ratios ( $\mathrm{ppb}$ ) for the gaseous tracers and in mass concentrations $\left(\mu \mathrm{g} \mathrm{m}^{3}\right)$ for the particles.

\subsection{Transport processes}

In the advection scheme (Walcek and Aleksic, 1998) the advection operator is performed sequentially in three dimensions. In principle the advection is a linear operator. But for 
the Walcek scheme, the concentration fluxes through the cell edges are calculated based on the fluxes between the two nearest upwind and the nearest downwind cells. The fluxes are limited by the maximum and minimum concentration of the two surrounding cells. Due to this application, the advection process is slightly non-linear.

For the update of the source allocation, the mass fluxes between all cells are passed to the labeling routine. The new source allocation in each cell is calculated with the source allocation of the remaining concentration and the sum over the source allocations of the influx(es) $F_{\text {in }}$ of the cell. The remaining concentration is the old concentration $c_{n-1}$ minus the sum of all the outfluxes, which has the same source allocation as the old concentration. The new source allocation is then the following:

$\boldsymbol{f} \boldsymbol{r}_{n}(l)=\frac{\boldsymbol{f} \boldsymbol{r}_{n-1}(l) \cdot\left(c_{n-1}-\frac{\boldsymbol{F}_{\text {out }} \cdot \Delta t}{V}\right)+\frac{\sum_{k=1}^{K} \boldsymbol{F}_{\mathrm{in}, k}(l) \cdot \Delta t}{V}}{c_{n}}$.

Here, $\boldsymbol{F}_{\text {out }}$ is the total mass or volume outflux $\left(\mu \mathrm{g} \mathrm{s}^{-1}\right.$ or $\left.\mathrm{m}^{3} \mathrm{~s}^{-1}\right)$, while $V$ is the volume $\left(\mathrm{m}^{3}\right)$ of the cell. The total number of neighbor cells is $K$. The mass or volume influx $\left(\mu \mathrm{g} \mathrm{s}^{-1}\right.$ or $\left.\mathrm{m}^{3} \mathrm{~s}^{-1}\right)$ per label is defined as

$\boldsymbol{F}_{\text {in }}(l)=\boldsymbol{f} \boldsymbol{r}_{n-1}(l)_{\text {in }} \cdot F_{\text {in }}$.

The fractions $\boldsymbol{f} \boldsymbol{r}_{\mathrm{n}-1}(l)_{\text {in }}$ for the mass influx $F_{\text {in }}$ are taken from the comparing donor cell.

All other processes that govern one-dimensional transport, i.e. diffusion, sedimentation and adjustment are implemented following the same approach. The influxes are stored and with those the new source allocation is calculated. The process adjustment accounts for the concentration changes due to the adaption of the vertical layering structure as a consequence of the rise and fall of the mixing layer.

\subsection{Wet and dry deposition}

Wet and dry deposition are important sinks in the model. As it is assumed that each molecule of a species has the same probability to be deposited, the source apportionment for the concentration arrays does not change. A complication is associated with the treatment of the re-emission of ammonia which is possible as the model includes the bi-directional surface-atmosphere exchange (Wichink Kruit et al., 2012). Here we assume that the exchange is fast and the source allocation of this emitted ammonia is given the same allocation as the concentration in air. Alternatively, one could store the source allocation of the ammonia deposition fluxes and use these for the re-emission flux. Given the short atmospheric lifetime and the dominant impact of agriculture for ammonia, we feel that both approaches would yield very similar results.

\subsection{Gas phase chemistry}

The gas phase chemistry in LOTOS-EUROS is described using a CBM4 mechanism. We aim to provide a source attribution that is valid for the current atmospheric conditions. As a consequence, the labeling process is only implemented for chemical active tracers with an $\mathrm{N}, \mathrm{C}$ or an $\mathrm{S}$ atom. These atoms are conserved and are traceable. This means that four oxidants $\left(\mathrm{OH}, \mathrm{H}_{2} \mathrm{O}_{2}, \mathrm{HO}_{2}\right.$ and $\left.\mathrm{O}_{3}\right)$ and two operator species $\left(\mathrm{XO}_{2}\right.$ and $\left.\mathrm{XO}_{2} \mathrm{~N}\right)$ are not traced.

Recent studies to the origin of ozone use a tagging method with duplicate tracers and reactions (Grewe, 2004; Butler et al., 2011; Dahlmann et al., 2011; Grewe et al., 2012). For this purpose one has to assume a $\mathrm{NO}_{\mathrm{x}}$ of volatile organic compounds (VOC) limited chemical regime. With the same assumptions the methodology outlined below could also be used for ozone. As the chemical limitation varies across Europe, a sensible application is not straightforward and therefore not pursuit here.

The following differential equation is solved to calculate the new concentrations of all species.

$$
\frac{\mathrm{d} c}{\mathrm{~d} t}=c_{\mathrm{p}}+c_{1} c
$$

Here, $c_{1}$ contains the loss rates $\left(\mathrm{s}^{-1}\right)$ and $c_{\mathrm{p}}$ contains the production rates $\left(\mathrm{ppb} \mathrm{s}^{-1}\right)$. Further, $c$ represents the concentration of a single tracer (ppb). This system is solved with a numerical implicit method, with the following result:

$c_{n}=\frac{c_{n-1}+\mathrm{d} t \cdot c_{\mathrm{p}}}{1+\mathrm{d} t \cdot c_{1}}$.

In here $c_{n-1}$ and $c_{n}$ are the new (at time $t+\mathrm{d} t$ ) and old (at time $t$ ) concentrations for each species.

The main assumption for the labeling for the chemistry is that first the species are produced before their loss is taken into account. For the source allocation of each species it is necessary to keep track of the produced material as function of its originating species containing the corresponding $\mathrm{C}, \mathrm{N}$ or $\mathrm{S}$ atom. One of the main advantages in the chemical scheme used in LOTOS-EUROS is that this information is easily available. From the solver the production rates split into origin of species are passed to the labeling routine using a square production matrix $\mathbf{Y}_{\mathrm{p}}\left(\mathrm{ppb} \mathrm{s}^{-1}\right)$ with the size of the number of labelled species. The columns indicate the reacted species, while the rows contain the produced species. For example: the entry with column index of $\mathrm{NO}$ and row index of $\mathrm{NO}_{2}$ corresponds with the produced $\mathrm{NO}_{2}$ out of $\mathrm{NO}$, which is a composition of all production rates that deal with production of $\mathrm{NO}_{2}$ out of NO. In the labeling routine, the new source contributions are calculated with the following formula:

$\boldsymbol{f} \boldsymbol{r}_{n}(l)=\frac{\boldsymbol{f} \boldsymbol{r}_{\mathrm{n}-1}(l) \cdot c_{\mathrm{n}-1}(l)+\mathrm{d} t \cdot \boldsymbol{f} \boldsymbol{r}_{\mathrm{n}-1}(l) \cdot \mathbf{Y}_{\mathrm{p}}}{c_{\mathrm{n}-1}+\mathrm{d} t \cdot c_{\mathrm{p}}}$. 
Here, $\boldsymbol{f} \boldsymbol{r}_{\mathrm{n}-1}(l)$ and $\boldsymbol{f} \boldsymbol{r}_{n}(l)$ are the old and new fractions of label $l$, while $c_{\mathrm{n}-1}(l)$ is the old concentration for label $l$. Note that the first multiplication in the numerator is a vector-vector multiplication, which multiplies the entries of both vectors one by one. The second multiplication is a full matrix-vector multiplication, which are generally computationally expensive. As the matrix $\mathbf{Y}_{\mathrm{p}}$ is sparse, a special routine for sparse matrices is used to save computer time.

To illustrate the process we use the reaction of nitrogen dioxide with the hydroxyl radical as an example:

$\mathrm{NO}_{2}+\mathrm{OH} \rightarrow \mathrm{HNO}_{3}$ with rate $k$.

This reaction produces nitric acid $\left(\mathrm{HNO}_{3}\right)$ and results in a loss of nitrogen dioxide $\left(\mathrm{NO}_{2}\right)$. The reaction clearly illustrates that the $\mathrm{N}$-atom is conserved. This reaction will lower the $\mathrm{NO}_{2}$ concentration but will not change the source apportionment of $\mathrm{NO}_{2}$ as all $\mathrm{NO}_{2}$ molecules have the same chance to react. The produced $\mathrm{HNO}_{3}$ has the origin of $\mathrm{NO}_{2}$. The new concentration per label for $\mathrm{HNO}_{3}\left(c_{n}\left(\mathrm{HNO}_{3}, l\right)\right)$ is calculated as follows (only the reaction above is involved):

$$
\begin{aligned}
& \boldsymbol{f} \boldsymbol{r}_{n}\left(\mathrm{HNO}_{3}, l\right)= \\
& \frac{c_{n-1}\left(\mathrm{HNO}_{3}\right) \cdot \boldsymbol{f} \boldsymbol{r}_{n-1}\left(\mathrm{HNO}_{3}, l\right)+\mathrm{Y}_{\mathrm{p}}\left(\mathrm{HNO}_{3}, \mathrm{NO}_{2}\right) \cdot \boldsymbol{f} \boldsymbol{r}_{\mathrm{n}-1}\left(\mathrm{NO}_{2}, l\right)}{c_{n-1}\left(\mathrm{HNO}_{3}\right)+c_{\mathrm{p}}\left(\mathrm{HNO}_{3}\right)} .
\end{aligned}
$$

With $\mathbf{Y}_{\mathrm{p}}\left(\mathrm{HNO}_{3}, \mathrm{NO}_{2}\right)=k \cdot\left[\mathrm{NO}_{2}\right] \cdot[\mathrm{OH}]$. The term $\mathbf{Y}_{\mathrm{p}}$ $\left(\mathrm{HNO}_{3}, \mathrm{NO}_{2}\right) \cdot \boldsymbol{f} \boldsymbol{r}_{\mathrm{n}-1}\left(\mathrm{NO}_{2}, l\right)$ corresponds with the label specific production of $\mathrm{HNO}_{3}$ from $\mathrm{NO}_{2}$. The term $c_{\mathrm{p}}\left(\mathrm{HNO}_{3}\right)$ corresponds with the total produced $\mathrm{HNO}_{3}$. In the case with only one reaction, this term is equal to $\mathbf{Y}_{\mathrm{p}}\left(\mathrm{HNO}_{3}, \mathrm{NO}_{2}\right)$.

In the current implementation it is assumed that for the production of species with $\mathrm{C}, \mathrm{N}$ or $\mathrm{S}$ atoms, the source apportionment is taken from the original species with the corresponding atom. This means that for reactions between organic compounds and nitrogen oxides such as the oxidation of formaldehyde by the $\mathrm{NO}_{3}$ radical, the origin of the produced $\mathrm{HNO}_{3}$ is taken from the that of $\mathrm{NO}_{3}$ while the origin of the produced $\mathrm{CO}$ is taken from that of formaldehyde. The reactions forming and dissociating peroxy acetyl nitrate (PAN) are an exception to this rule as PAN combines both C and $\mathrm{N}$ atoms in a single molecule. It is an important reservoir species and may be transported over quite a distance. At some point PAN will dissociate, but within the current implementation there is no way to keep track of the original $\mathrm{N}$ or $\mathrm{C}$ source contributions. Therefore, the source apportionment of the produced PAN is taken from both precursor species $\left(\mathrm{C}_{2} \mathrm{O}_{3}\right.$ and $\left.\mathrm{NO}_{2}\right)$. For the dissociation reaction the normal procedure is followed. Consequently, this is the only way for sources without an $\mathrm{N}$-emission to receive a small but non-zero contribution to the $\mathrm{N}$-species. Note that the current implementation enables excluding the labeling of the $\mathrm{C}$ atoms by limiting the $\mathbf{Y}_{\mathrm{p}}$ matrix to the inorganic chemistry only. This feature was implemented as an option as it gives a slightly more accurate source allocation for the inorganic species and, more importantly, reduces computing time since the matrix vector multiplication is much smaller. In this study the full source apportionment is used.

\subsection{Aerosol chemistry}

The source apportionment of non-volatile aerosol components, such as sulfate and sodium nitrate, is straightforward and follows the approach outlined for the gas phase chemistry. However, a different approach is taken for a semivolatile component such as ammonium nitrate. The thermodynamic equilibrium module ISORROPIA-II is used in LOTOS-EUROS to assess the partitioning between nitric acid $\left(\mathrm{HNO}_{3}\right)$ and nitrate $\left(\mathrm{NO}_{3}\right)$, as well as between ammonia $\left(\mathrm{NH}_{3}\right)$ and the ammonium $\left(\mathrm{NH}_{4}\right)$. In a thermodynamic equilibrium the exchange between the gas to aerosol phase is by definition equal. Though no net mass is exchanged, the constant exchange between the two phases will cause the origin of the gas and aerosol phase to equalize. Hence, after the equilibrium calculation the source attribution of nitrate (ammonium) and nitric acid (ammonia) are averaged:

$$
\begin{aligned}
& \boldsymbol{f} \boldsymbol{r}_{n}\left(\mathrm{HNO}_{3}\right)=\boldsymbol{f} \boldsymbol{r}_{n}\left(\mathrm{NO}_{3}\right)= \\
& \frac{\boldsymbol{f} \boldsymbol{r}_{n-1}\left(\mathrm{HNO}_{3}\right) \cdot c_{n-1}\left(\mathrm{HNO}_{3}\right)+\boldsymbol{f} \boldsymbol{r}_{n-1}\left(\mathrm{NO}_{3}\right) \cdot c_{n-1}\left(\mathrm{NO}_{3}\right)}{c_{n-1}\left(\mathrm{HNO}_{3}\right)+c_{\mathrm{n}-1}\left(\mathrm{NO}_{3}\right)} \\
& \boldsymbol{f} \boldsymbol{r}_{n}\left(\mathrm{NH}_{3}\right)=\boldsymbol{f} \boldsymbol{r}_{n}\left(\mathrm{NH}_{4}\right)= \\
& \frac{\boldsymbol{f} \boldsymbol{r}_{n-1}\left(\mathrm{NH}_{3}\right) \cdot c_{n-1}\left(\mathrm{NH}_{3}\right)+\boldsymbol{f} \boldsymbol{r}_{n-1}\left(\mathrm{NH}_{4}\right) \cdot c_{n-1}\left(\mathrm{NH}_{4}\right)}{c_{n-1}\left(\mathrm{NH}_{3}\right)+c_{n-1}\left(\mathrm{NH}_{4}\right)} .
\end{aligned}
$$

\section{Technical validation}

The development and implementation of the labeling technique was performed for each process at a time. The correct functioning of the code was evaluated with dedicated experiments. For the emission, vertical diffusion, deposition and adjust processes a simple experiment could be designed as their solution is refined to a single column and the processes are linear. For advection a more elaborate and indirect experiment was performed. Below we present the performance evaluation for these cases. Note, for the chemistry, the functioning of the module is illustrated in Sect. 5 as it is not possible to give a technical validation.

\subsection{Case 1: linear processes}

To test the labeling technique for the linear processes emission, deposition, diffusion, sedimentation and adjust, the LOTOS-EUROS model was run for the month of January 2007, for primary PM components. These include:

- EC fine: Elemental Carbon in fine mode $\left(\mathrm{EC}_{\mathrm{f}}\right)$

- PPM fine: Primary Particulate Matter in fine mode $\left(\mathrm{PPM}_{\mathrm{f}}\right)$ 
- PPM coarse: Primary Particulate Matter in coarse mode $\left(\mathrm{PPM}_{\mathrm{c}}\right)$

The $\mathrm{EC}_{\mathrm{f}}$ emissions are estimated as a percentage of the fine mode primary PM $\left(\mathrm{PPM}_{\mathrm{f}}\right)$ emissions using sector dependent factors (Schaap et al., 2004). This approach enabled defining a simulation in which the $\mathrm{EC}_{\mathrm{f}}$ concentration is calculated as a separate tracer and compared to a labelled $\mathrm{EC}_{\mathrm{f}}$ fraction of the $\mathrm{PPM}_{\mathrm{f}}$ concentration. Thus, within this simulation the $\mathrm{EC}_{\mathrm{f}}$ fraction of all primary PM components was labelled using five labels:

- Fraction $\mathrm{EC}_{\mathrm{f}}$

- Fraction not $\mathrm{EC}_{\mathrm{f}}$

- Boundary conditions (north, east, south and west boundaries)

- Initial condition

- Aloft boundary condition (boundary on top of the domain)

As the boundary and initial conditions were set to zero, their fraction should remain zero. Moreover, the fractions of $\mathrm{EC}_{\mathrm{f}}$ for components $\mathrm{EC}_{\mathrm{f}}$ and $\mathrm{PPM}_{\mathrm{c}}$ should remain 1 and 0 , respectively, which they did. The contribution of EC in $\mathrm{PPM}_{\mathrm{f}}$ should equal the $\mathrm{EC}_{\mathrm{f}}$ concentration in the model. In Fig. 1, the results are shown for the combination of the linear processes in the model. The results show that the fractions of label $\mathrm{EC}_{\mathrm{f}}$ for $\mathrm{PPM}_{\mathrm{f}}$ fits perfectly on the ratio between $\mathrm{EC}_{\mathrm{f}}$ and $\mathrm{PPM}_{\mathrm{f}}$. There are small deviations which are caused by the numerical precision in the computations. Tests using all linear processes separately yields the same results. From these experiments it is clear that the source allocation routine for these processes functions correctly.

\subsection{Case 2: advection}

In the second performance test we add the advection process to the system. We perform an annual simulation for 2007 for a small domain centred around the Netherlands including the Netherlands, Belgium, northern France and the western part of Germany. Simulations were performed for the full year of 2007. The labels were defined to represent the geographical areas:

- Belgian emissions

- German emissions

- Dutch emissions

- Emissions from other countries or seas

- Boundary conditions

- Initial conditions

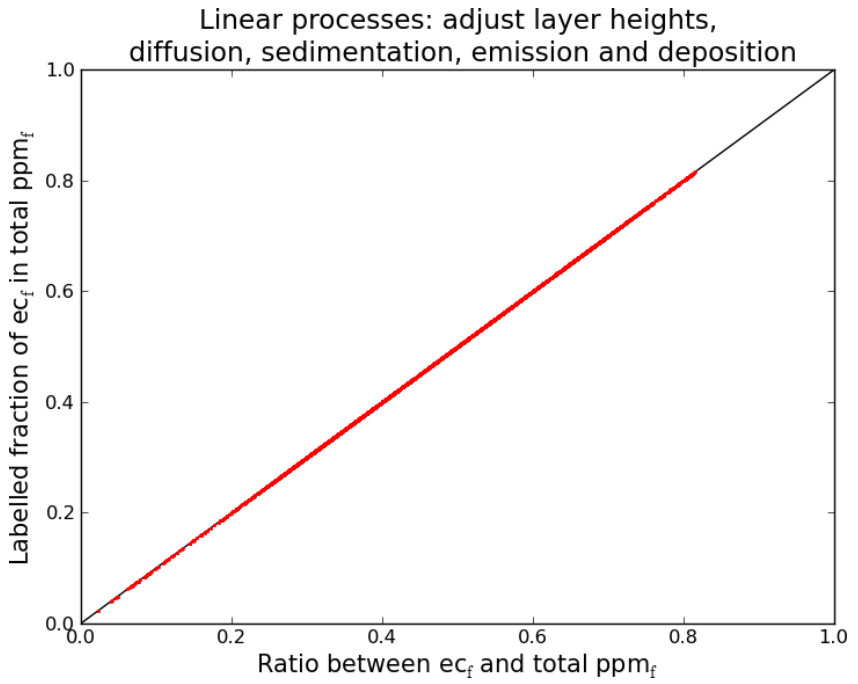

Fig. 1. Scatter plot of the ratio between fine elemental carbon (EC_f) and total primary PM in the fine mode (PPM_f) against the labelled fraction of EC_f in PPM_f. This scatter plot is valid for the linear processes: Adjust layer heights, vertical diffusion, sedimentation, emission and deposition.

\section{- Aloft boundary condition}

The results of this labeling simulation were compared to four scenario simulations in which only the one of the mentioned regions emit their emissions. As the primary species are treated to be inert, the system is linear except for the advection and a close resemblance is expected.

In Fig. 2 we present the results for the Dutch contribution to the modelled EC concentration. The annual mean EC distribution for the scenario run containing Dutch emissions (upper left) closely resembles that of the Dutch labelled concentrations for the full model simulation (upper right). The differences between the estimates for the Dutch EC contribution differs at most by $4 \%$ (lower panel). These small differences are induced by the Walcek advection algorithm in which the fluxes through the cell edges are calculated as a weighted average of one downwind and two upwind cells. In case of scenario simulations with different concentrations gradients the fluxes through the cell edges will slightly differ between the simulations. This becomes mostly visible around large source areas. Also the impact of the border is visible in the difference due to the steep concentration gradient across the border in case of a scenario run. In a labeling simulation all sources are included and the impact of differences in gradients are avoided. As such, one could argue that the labeling technique provides a more consistent approach than scenario simulations.

\subsection{Computational cost}

Here we compare the computational cost of a labeling simulation with $n$ sectors to a brute force source apportionment 

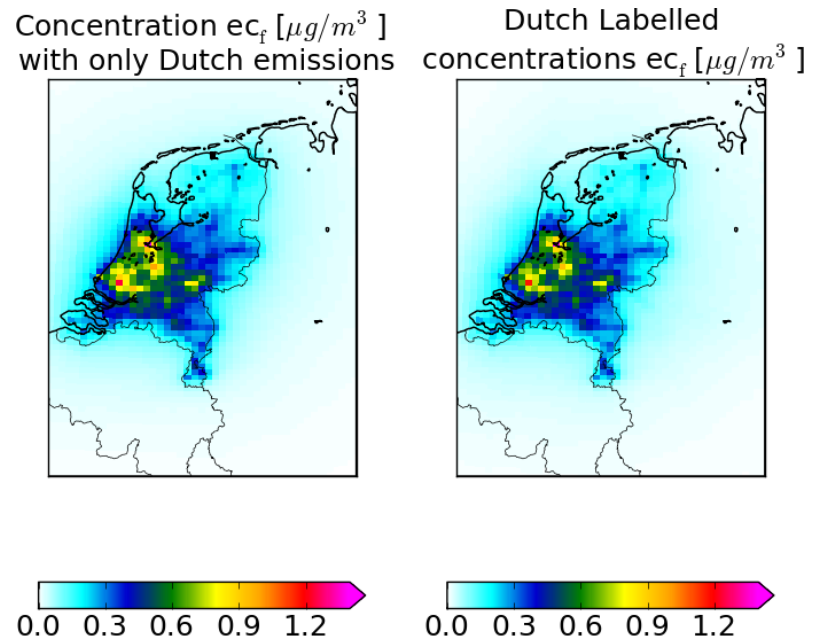

Difference between only Dutch emitted $\mathrm{ec}_{\mathrm{f}}$ and Dutch labeled ec $\mathrm{f}\left[\mu \mathrm{g} / \mathrm{m}^{3}\right.$ ]

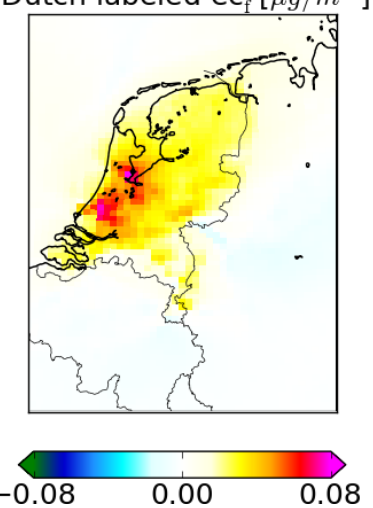

Fig. 2. Upper left: concentration elemental carbon in fine mode (EC_f) resulting from a model simulation with only Dutch emissions. Upper right: concentration EC_f from a full model simulation corresponding to the label on Dutch emissions. Lower: the difference between those two simulations. These simulations are done with the linear processes and the non-linear advection process for the complete year 2006.

effort containing $n$ scenarios. The computational time of single simulation using the source apportionment tool is larger than for a single scenario due to the additional bookkeeping and calculations. However, it is only a fraction of the total of all scenario runs. In Fig. 7 the computation time using the new tool as a fraction of the computation time for $n$ scenario runs is given for both simulations with inert and chemically active components. The graph shows that the computer time saved increases with the number of labels. For example, with $n=24$ labels and inert tracers one needs only about 17 percent of the computational time compared to 24 scenario runs. In case the full chemistry is added, the profit is somewhat smaller as the chemistry is the most expensive part in LOTOS-EUROS. Still, the computational costs with 24 labels are about a factor 4 lower than using scenario runs. The sharp decrease in run time for only a few labels can be explained by the overhead cost. Within one run, the computational cost of reading and processing the input data is relatively large.

\section{Illustration of the labeling approach for chemical active tracers}

In principle, it is impossible to give a technical validation of the functioning of the labeling routine for a full chemistry simulation as the chemistry scheme is non-linear. Comparing a labeling to a scenario simulation will show the impact of indirect effects through changes in oxidant levels and the change in pollutant levels. Hence scenario calculations cannot provide a real benchmark for the chemistry (Emmons et al., 2012; Grewe et al., 2012). Still, to illustrate the functioning of the module, we compare a simulation in which we label a relatively small fraction $(5 \%)$ of the Dutch emissions to a scenario simulation with the same emission reduction on all anthropogenic sources. The simulations were performed for July 2006 with active photochemistry. Results are discussed for three components with a different origin and lifetime (carbon monoxide, methylglyoxal and nitrogen oxides). We first compare the results for carbon monoxide (CO) as its chemistry is relatively simple, it has a long life time and has strong anthropogenic sources. Hence, the impact of changes in chemical regime is expected to be small. Next, we compare the results of a reaction product from the degradation of non-methane volatile organic compounds (NMVOC) being methylglyoxal (MGLY). This species has a short life time and is largely determined by oxidation of biogenic VOC. Hence, the impact of the chemical regime is expected to be very large. Finally, we discuss $\mathrm{NO}$ and $\mathrm{NO}_{2}$ as they behave typically due to the impact of the photo-stationary equilibrium.

In Fig. 3 the labelled $5 \%$ contribution (upper left) is compared to the impact of the $5 \%$ emission reduction (upper right). Both simulations produce a $\mathrm{CO}$ contribution of about $2 \mathrm{ppb}$ in the Randstad, with lower values in the more rural part of the Netherlands and highest values in industrialized areas. The difference between both results (Fig. 3: lower panel) is an order of magnitude lower than the estimated $5 \%$ contribution itself. The non-linearity in the chemistry (and the transport) provides a difference of about $2-10 \%$ in the estimated Dutch contribution, which we consider to be relatively small. As the Netherlands is characterized by very high $\mathrm{NO}_{\mathrm{x}}$ emissions, the difference can be explained by a net increase in oxidant levels in the scenario simulation due to the decreasing impact of ozone titration.

In Fig. 4 the results are shown for MGLY, a reaction product of the degradation of NMVOC. Comparison between the labelled contribution and the scenario difference shows a large difference. The labelled 5\% Dutch contribution is a factor 3 higher than the concentration difference due to a $5 \%$ reduction in all Dutch emissions. In addition, the patterns 

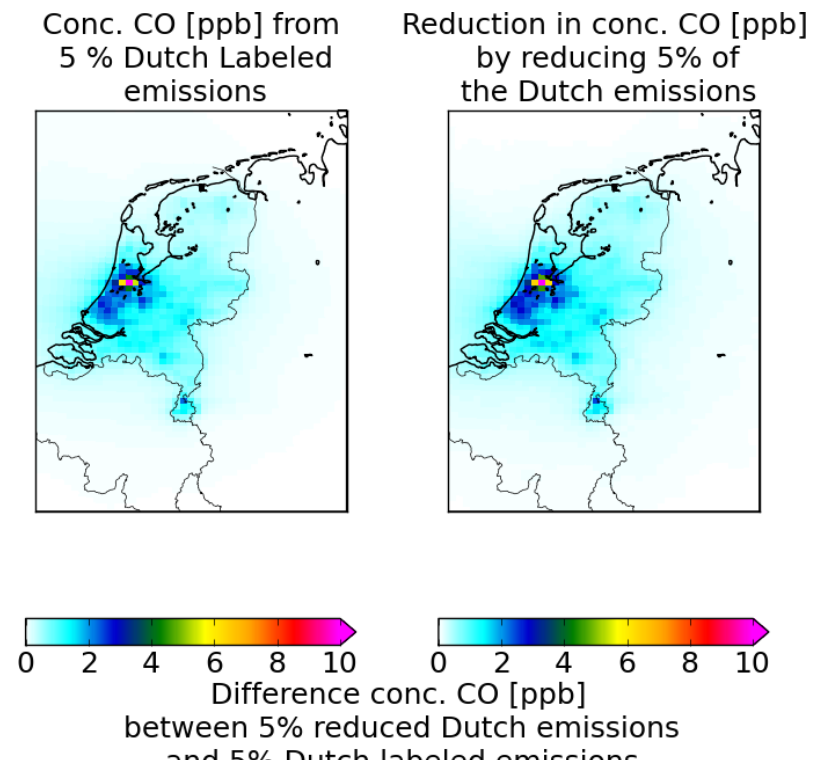

and $5 \%$ Dutch labeled emissions

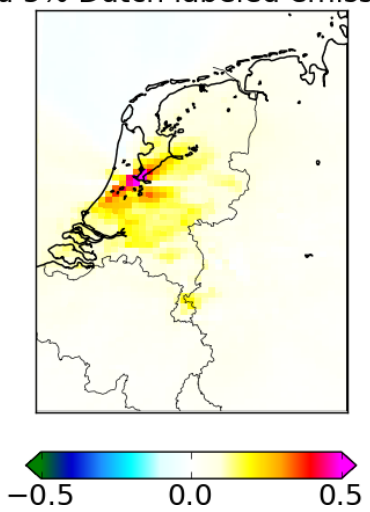

Fig. 3. Upper left: concentration carbon monoxide from a full model simulation corresponding to $5 \%$ of the Dutch emissions. Upper right: carbon monoxide concentrations from a full simulation minus concentration from a simulation with $5 \%$ reduced Dutch emissions. Lower: the difference between those two. These simulations are valid for the month July of 2006.

are not all the same. We expect that the change in chemical regime impacting all formation and destruction routes has a large impact on the estimated contribution based on the scenario. To validate this assumption a second simulation was performed with only a $5 \%$ reduction on the Dutch NMVOC emissions, keeping all other emissions the same. The lower right panel of Fig. 4 shows the concentration change for MGLY for this simulation. The results are much closer to the labelled simulation, both in magnitude and gradients. Differences are now at most $10 \%$ and occur in regions where anthropogenic emissions are largest and non-linearity in the chemistry and its impact on the solver is expected to be largest. The close agreement provides confidence in the functioning of the source apportionment module. These results also clearly illustrate the difference between source apportionment based on scenarios versus a labeling technique.
Conc. MGLY [ppb] from $5 \%$ Dutch Labeled emissions
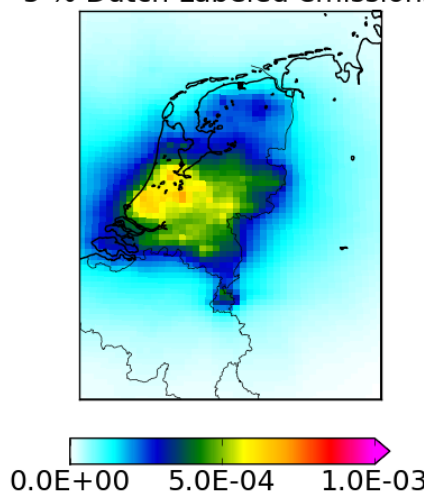

Reduction in conc. Reduction in conc. MGLY MGLY [ppb] by reducing $5 \%$ [ppb] by reducing $5 \%$ of the of the Dutch emissions Dutch NMVOC emissions
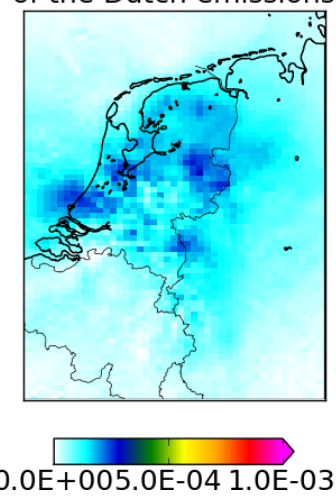

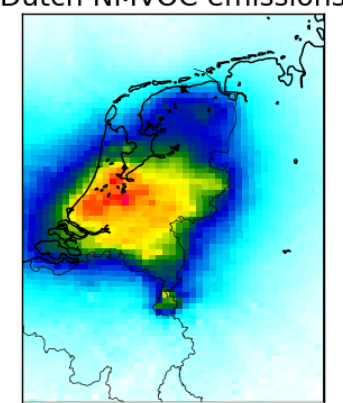

0.0E+005.0E-04 1.0E-03
Fig. 4. Upper: concentration methylglyoxal (MGLY) from a full model simulation corresponding with the $5 \%$ labelled Dutch emissions. Lower left: MGLY concentrations from a full simulation minus concentration from a simulation with $5 \%$ reduced Dutch anthropogenic emissions. Lower right: MGLY concentrations from a full simulation minus concentration from a simulation with $5 \%$ reduced Dutch anthropogenic NMVOC emissions. These simulations are valid for the month July of 2006.

Considering the photo stationary equilibrium between NO and $\mathrm{NO}_{2}$ a difference in results is also anticipated for results of these components. $\mathrm{NO}_{\mathrm{x}}$ is largely emitted in the form of NO. NO reacts rapidly with ozone to form $\mathrm{NO}_{2}$. The photolysis reaction of $\mathrm{NO}_{2}$ during daylight establishes an equilibrium during the day, though $\mathrm{NO}$ concentrations in the presence of ozone are only a fraction of that of $\mathrm{NO}_{2}$. Due to the rapid conversion during the day, the source apportionment of $\mathrm{NO}$ and $\mathrm{NO}_{2}$ will be equal. In Fig. 5 the relative reduction of the $\mathrm{NO}_{2}$ and $\mathrm{NO}$ concentrations are presented for the simulation with $5 \%$ reduced Dutch emissions. These figures show that the impact on $\mathrm{NO}_{2}$ is a little less than $5 \%$ while the impact on NO is mostly larger than $5 \%$. The explanation lies in the difference in the extent of titration between the two runs. Consider a box with a certain amount of ozone. In case this amount has been fully titrated, a reduction in NO emissions 

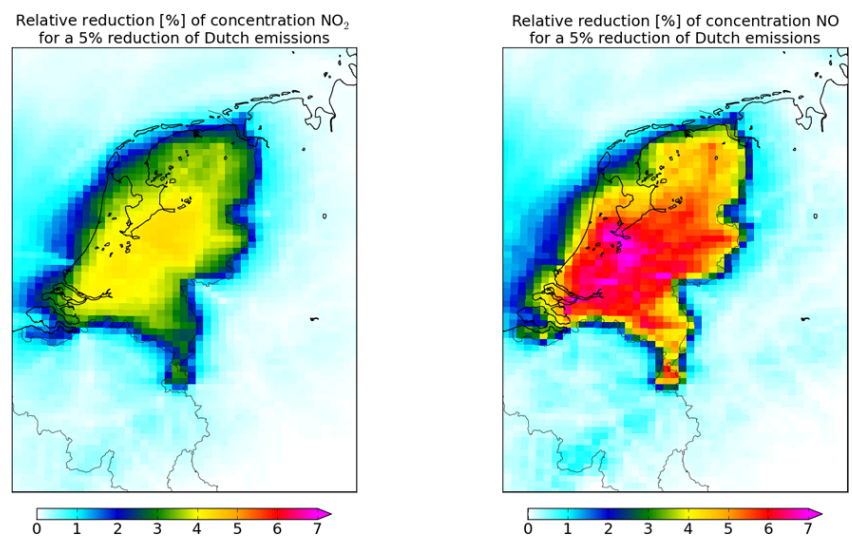

Fig. 5. Relative reduction of concentration $\mathrm{NO}_{2}$ (left) and $\mathrm{NO}$ (right) by a reduction of $5 \%$ of the Dutch emissions. These simulations are valid for the month July of 2006.

may not impact $\mathrm{NO}_{2}$ but will impact $\mathrm{NO}$ to a larger extend. This feature is clearly visible in the scenario results. The case shows that the first reduction on $\mathrm{NO}_{\mathrm{x}}$ emissions will not be most effective to reduce $\mathrm{NO}_{2}$ levels evidenced by the lower than $5 \%$ impact on $\mathrm{NO}_{2}$. However, in a mixture of emission sources all contributions have the same probability to react. The labeling simulation therefore yields much closer values to $5 \%$, which is the actual anticipated result (Fig. 6). Again, these results show the functioning of the module and the advantage it may have on a brute force study based on scenario studies.

\section{Application to the origin of nitrate across the Netherlands}

To demonstrate the potential applications of the source apportionment module, we provide an assessment of the origin of particulate nitrate across the Netherlands. The majority of the nitrate in the Netherlands is present in the form of ammonium nitrate, whereas coarse mode (sodium) nitrate contributes a minor part (Weijers et al., 2011; Ten Brink et al., 1997). Both formation mechanisms are present in the LOTOS-EUROS model. Annual mean modelled concentrations underestimate the observed nitrate concentrations by about $20 \%$. Evaluation against daily particulate matter samples (Hendriks et al., 2013) as well as hourly observations (Schaap et al., 2011) show that the model is able to capture the variability in time quite well. For a detailed discussion on the model performance and associated uncertainties we refer to these papers. Here, we present the source apportionment for nitrate obtained with a simulation in which labels were defined to track the national and foreign contributions of all SNAP level 1 emission sectors (20 in total). Note that the interpretation of the results was also made for all PM components and is presented in detail in Hendriks et al. (2013).
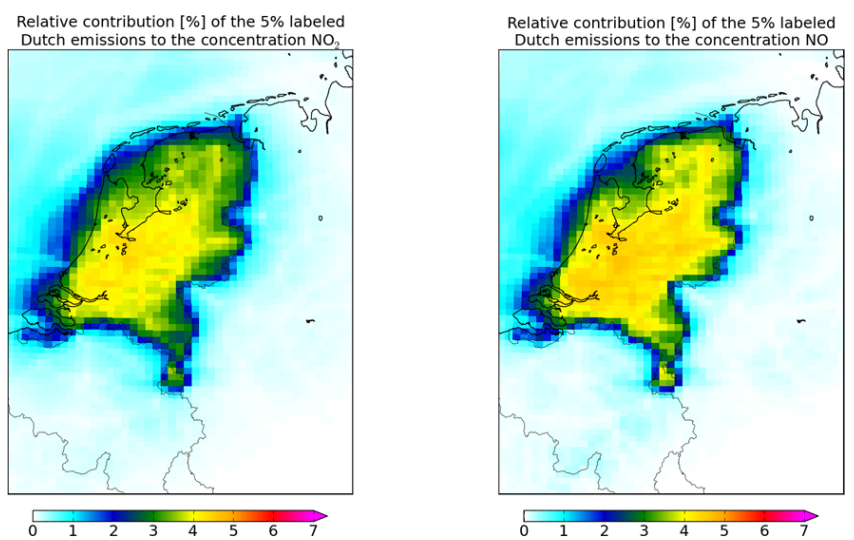

Fig. 6. Relative contribution of the $5 \%$ labelled Dutch emissions to the total concentration of $\mathrm{NO}_{2}$ (left) and $\mathrm{NO}$ (right). These simulations are valid for the month July of 2006.

Averaged across the Dutch territory, the main contributions to nitrate are derived from road transport (30\%), other transport (25\%) and power plants (15\%). Overall, only $20 \%$ of the concentration are derived from sources located inside the country, which is explained by the secondary nature of nitrate, the relatively small size of the country and peak nitrate concentrations that occur during anti-cyclonic conditions with transport of polluted air masses from important source areas to the south (Flanders) and east (Ruhr area) of the country. These results are shown in Fig. 8. To investigate whether the origin differs as function of the modelled nitrate concentration the daily average nitrate values were categorized and the origin was plotted as function of concentration in Fig. 8. Surprisingly, the national contribution is relatively constant over the range of concentrations for the Netherlands as a whole. Only for the populated Randstad area (e.g. Rotterdam) in the west of the country, the national contribution increases with increasing concentrations. At concentrations above $10 \mu \mathrm{g} \mathrm{m}^{-3}$, about $30 \%$ of the modelled nitrate is of national origin. Investigating the sectoral contributions shows that off-road transport contributions decrease with increasing nitrate levels. This can be explained by the dominant impact of international shipping on the North Sea, which is highest during westerly flows and thus clean air conditions in the Netherlands. The decreasing share of off-road transport is compensated by an increase of road transport and power generation. The modelled source attribution is location dependent. A clear example is the distribution of the foreign off-road transport contribution (Fig. 9). The modelled contributions show a distribution with maximum absolute concentrations near the coast line, trailing off away from the coast. The maximum contributions along the coast can be explained by the formation mechanism of ammonium nitrate. Above sea, $\mathrm{NO}_{\mathrm{x}}$ emissions are effectively converted to nitric acid by the pool of oxidants present. However, ammonia is not present in large quantities and the reaction with sea salt is 


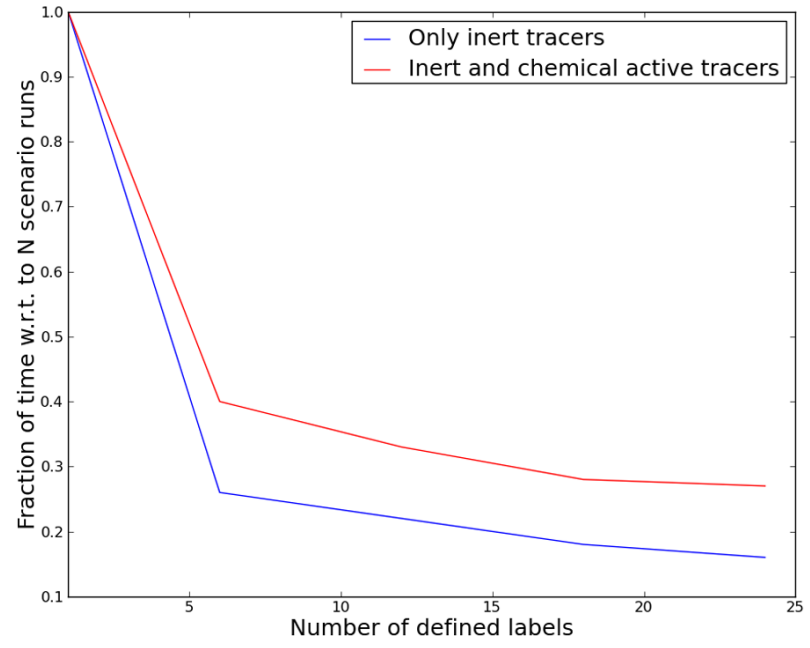

Fig. 7. Time efficiency of the labeling module with respect to the scenario approach. On the $\mathrm{x}$-axis the number of labels (sources of interest) defined. On the $y$-axis the relative fraction of computation time with respect to the total computation time of all needed scenarios run (for each source of interest a separate scenario run).

not very fast, limiting the aerosol nitrate formation. However, when the air mass reaches the main land with intense ammonia emissions the formation ammonium nitrate becomes effective, explaining the maximum along the coast line.

The examples above show that system is able to track the origin of components with complex formation pathways. The system presently tracks the source contributions to oxidized (e.g. nitrogen oxides) and reduced (e.g. ammonia) nitrogen species separately. Hence, the origin of nitrate is not connected to that of ammonia, which is needed to form ammonium nitrate. Hence, ammonium nitrate is one of the few examples where the interaction between the different labelled classes is important. The present approach that was chosen as the implementation is clear and results are easily explainable. An alternative could be to perform a post processing by attributing the mass of ammonium nitrate equally to the origin of ammonia and fine mode nitrate. As ammonia is derived more than $90 \%$ from agriculture, the alternative approach shows that agriculture contributes almost half of the nitrate mass (Fig. 8), whereas the contributions of all other sectors are almost halved. Also, the national contribution increases as ammonia has a shorter lifetime than oxidized nitrogen. Hence, it advised to provide results for both approaches in future studies.

\section{Conclusions}

We have developed and demonstrated a new module to investigate source contributions to modelled air pollutant distributions. We feel that the labeling module provides more accurate information about the source contributions than using
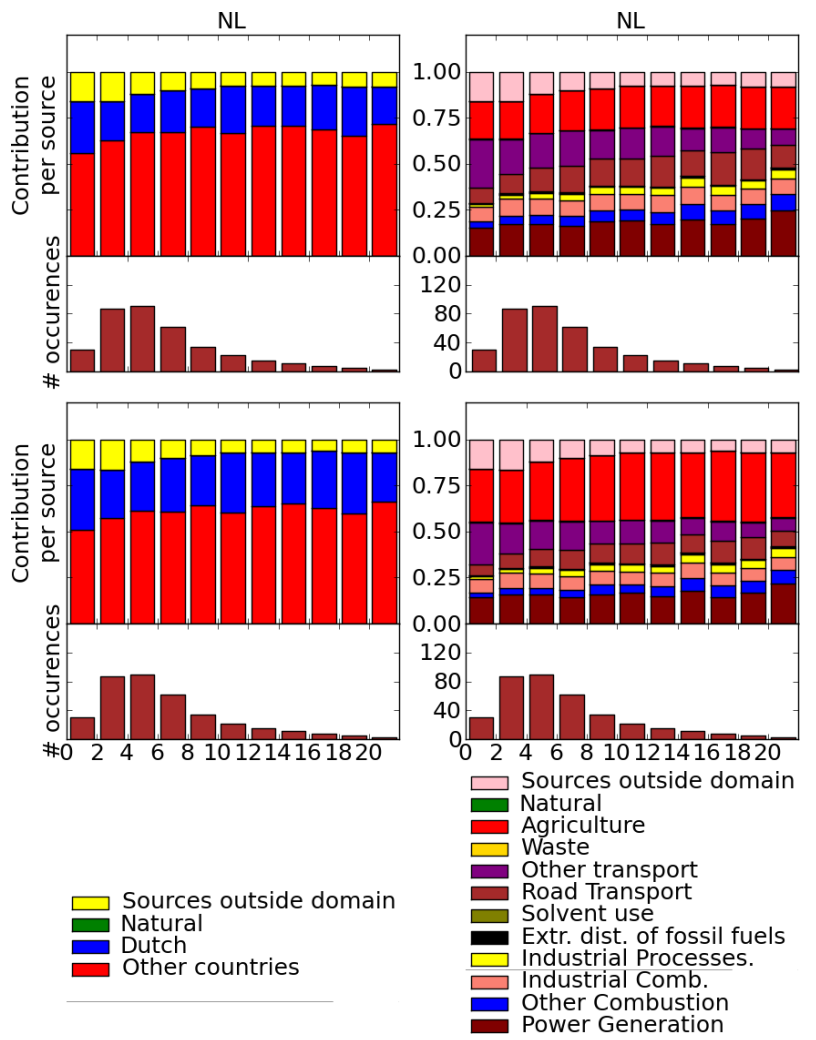

Fig. 8. Contributions of Dutch, foreign, natural and boundary sources (left) and anthropogenic source sectors (right) to nitrate concentrations averaged over the Netherlands. The attribution is shown as a function of nitrate levels on the $\mathrm{x}$-axis. The upper panels present the default source attribution. The lower panels present the source attribution corrected for the ammonium nitrate assumption
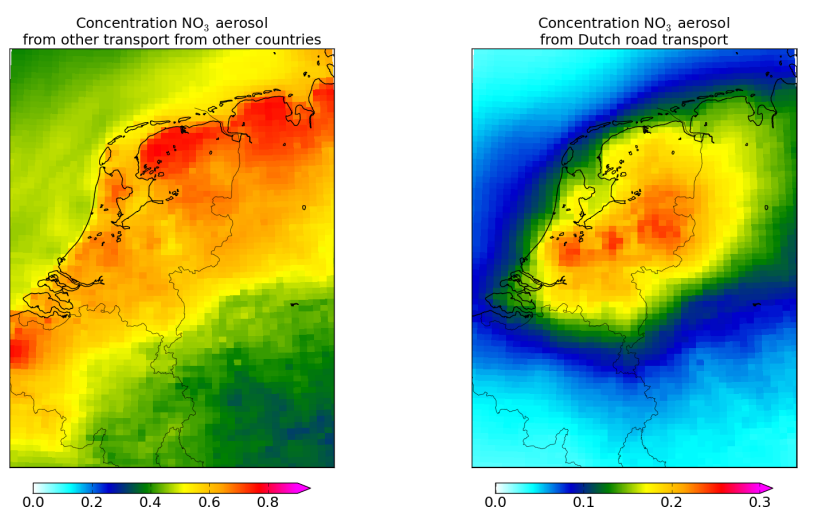

Fig. 9. Modelled source contributions of foreign non-road transport and Dutch road transport to nitrate concentrations $\left(\mu \mathrm{g} \mathrm{m}^{-3}\right)$ across the Netherlands.

a brute force approach with scenario runs as the chemical regime remains unchanged. As many components are not inert or nowadays considered to be non-inert (e.g. primary organic matter) the ability to make a proper source allocation is enhanced. With the labeling module it is possible to do 
so for most species and a reasonable number of sources in one simulation. In principle, the selection of sources is flexible and can be set by the modeller. An important advantage of the new module is the reduction computation costs associated with the calculations. Not only the computer time is reduced, also the preparation of a labeling simulation requires less work than setting up N scenarios. Moreover, using a single emission database and model simulations reduces the amount of errors and recalculations. The new technology opened new research directions for, for example, the interpretation of monitoring and remote sensing data (Hendriks et al., 2013) as well as the derivation of source receptor matrices.

Acknowledgements. This study was partly funded by the 7 th Framework Programme of the European Commission EnerGEO (see http://www.energeo-project.eu) and by the Dutch cooperation of model and data centers (NMDC).

Edited by: T. Butler

\section{References}

Banzhaf, S., Schaap, M., Kerschbaumer, A., Reimer, E., Stern, R., van der Swaluw, E., and Builtjes, P.: Implementation and evaluation of $\mathrm{pH}$-dependent cloud chemistry and wet deposition in the chemical transport model REM-Calgrid, Atmos. Environ., 49, 378-390,doi:10.1016/j.atmosenv.2011.10.069, 2011.

Bobbink, R., Hicks, K., Galloway, J., Spranger, T., Alkemade, R., Ashmore, M., Bustamnte, M., Cinderby, S., Davidson, E., Dentemer, F., Emmett, B., Erisman, J-W., Fenn, M., Gilliam, F., Nordin, A., Pardo, L., and de Vries, W.: Global assessment of nitrogen deposition effects on terrestrial plant diversity: a synthesis, Ecol. Appl., 20, 30-59, doi:10.1890/08-1140.1, 2010.

Butler, T. M., Lawrence, M. G., Taraborelli, D., and Lelieveld, J.: Multi-day ozone production potential of volatile organic compounds calculated with a tagging approach, Atmos. Environ., 45, 4082-4090, 2011.

Cuvelier, C., Thunis, P., Vautard, R., Amann, M., Bessagnet, B., Bedogni, M., Berkowicz, R., Brandt, J., Brocheton, F., Builtjes, P., Coppalle, A., Denby, B., Douros, G., Graf, A., Hellmuth, O., Honoré, C., Hodzic, A., Jonson, J., Kerschbaumer, A., de Leeuw, F., Minguzzi, E., Moussiopoulos, N., Pertot, C., Pirovano, G., Rouil, L., Schaap, M., Stern, R., Tarrason, L., Vignati, E., Volta, M., White, L., Wind, P., and Zuber, A.: CityDelta: A model intercomparison study to explore the impact of emission reductions in European cities in 2010, Atmos. Environ., 41, 189-207, 2007.

Dahlmann, V., Grewe, V., Ponater, M., and Matthes, S.: Quantifying the contributions of individual $\mathrm{NO}_{\mathrm{x}}$ sources to the trend in ozone radiative forcing, Atmos. Environ., 45, 2860-2868, 2011.

Dockery, D. W., Pope, C. A., Xu, X., Spengler, J. D. Ware, J. H. Fay, M. E., Ferris, B. G., and Speizer, F. E.: Ann association between air pollution and mortality in six US cities, New Engl. J. Med., 329, 1753-1759, 1993.

Emmons, L. K., Hess, P. G., Lamarque, J.-F., and Pfister, G. G.: Tagged ozone mechanism for MOZART-4, CAM-chem and other chemical transport models, Geosci. Model Dev., 5, 15311542, doi:10.5194/gmd-5-1531-2012, 2012.

Erisman, J. W., van Pul, A., and Wyers, P.: Parametrization of surface-resistance for the quantification of atmospheric deposition of acidifying pollutants and ozone, Atmos. Environ., 28, 2595-2607, 1994.

Forster, P., Ramaswamy, V., Artaxo, P., Berntsen, T., Betts, E., Fahey, D. W., Haywood, J., Lean, J., Lowe, D. C., Myhre, G., Nganga, J., Prinn, R., Raga, G., Schulz, M., and van Dorland, R.: Changes in Atmospheric Constituents and in Radiative Forcing,. In: Climate Change 2007: The Physical Science Basis. Contibuting of Working Group I to the fourth assessment Report of the intergovernmental Panel on Climate Change, edited by: Solomon, S., Qin, D., Manning, M., Chen, Z., Marquis, M., Averyt, K. B., Tignor, M., and Miller, H. L., Cambridge University Press, Cambridge, United Kingdom and New York, NY, USA, 2007.

Grewe, V.: Technical Note: A diagnostic for ozone contributions of various $\mathrm{NO}_{\mathrm{x}}$ emissions in multi-decadal chemistryclimate model simulations, Atmos. Chem. Phys., 4, 729-736, doi:10.5194/acp-4-729-2004, 2004.

Grewe, V., Tsati, E., and Hoor, P.: On the attribution of contributions of atmospheric trace gases to emissions in atmospheric model applications, Geosci. Model Dev., 3, 487-499, doi:10.5194/gmd3-487-2010, 2010.

Grewe, V., Dahlmann, K., Matthes, S., and Steinbrecht, W.: Attibuting ozone to $\mathrm{NO}_{\mathrm{x}}$ emissions: Implications for climate mitigation measures, Atmos. Environ., 59, 102-107, 2012.

Hass, H. Builtjes, P. J. H, Simpson, D., and Stern, R.: Comparison of model results obtained with several Europen regional air quality models, Atmos. Environ., 31, 3259-3279, 1997.

Hass, H., van Loon, M., Kessler, C., Stern, R., Matthijsen, J., Sauter, F., Zlatev, Z., Langner, J., Foltescu, V., and Schaap, M.: Aerosol Modeling: Results and Intercomparison from European Regioanl-scale Modeling Systems. A contribution to the EUROTRAC-2 subproject GLOREAM, available at: http://www.rivm.nl/bibliotheek/ digitaaldepot/GLOREAM_PMmodel-comparison.pdf (last access: 31 May 2013), April 2003.

Hendriks, C., Kranenburg, R., Kuenen, J. P. P., van Gijlswijk, Wichink Kruit, R. J., Segers, A.J., R. N., Denier van der Gon, H. A. C., and Schaap, M.: The origin of ambient particulate matter concentrations in the Netherlands, Atmos. Environ., 69, 289303, doi:10.1016/j.atmosenv.2012.12.017, 2013.

Klemm, R. J., Mason Jr., R. M., Heilig, C. M., Neas, L. M., and Dockery, D. W.: Is Daily Mortality Associated Specifically with Fine Particles? Data Reconstruction and Replication of Analyses, J. Air Waste Manage. Assoc., 50, 1215-1222, 2000.

Koeble, R. and Seufert, G.: Novel maps for forest tree species in Europe, Proceedings of the conference "a changing atmosphere", 17-20 September, Torino, Italy, 2001.

Kuenen, J. J. P., Denier van der Gon, H. A. C., Visschedijk, A., van der Brugh, H., and Van Gijlswijk, R.: MACC European emission inventory for the years 2003-2007, TNO Report TNO-060-UT2011-00588, Utrecht, The Netherlands, 2011.

Lane, T. E., Pinder, R. W., Shrivastana, M., Robinson, A. L., and Pandis, S. N.: Source contributions to primary organic aerosol: comparison of the results of a source resolved model and the chemical mass balance approach, Atmos. Environ., 41, 37583776, 2007. 
Mårtensson, E. M., Nilsson, E. D., De Leeuw, G., Cohen, L. H., and Hansson, H.: Labaratory Simulations and parameterization of the primary marine aerosol production, J. Geophys. Res.-Atmos., 108, AAC15-1-AAC15-12, 2003.

McHenry, J. H., Binkowski, F. S., Dennis, R. L., Chang, J. S., and Hopkins, D.: The Tagged Species Engineering Model (TSEM), Atmos. Environ., 26A, 1427-1443, 1992.

Monahan, E. C., Spiel, D. E., and Davidson, K. L.: A model of marine aerosol generation via whitecaps and wave disruption, Oceanic Whitecaps 1986, 167-174, 1986.

Nenes, A., Pandis, S. N., and Pilinis, C.: ISORROPIA: A new thermo dynamic equilibrium model for multiphase multicomponent inorganic aerosols, Aquat. Geochem., 4, 123-152, 1998.

Putaud, J. P., Dingenen, R., Alasteuy, A., Bauer, H., Birmili, W., Cyrys, J., Flentje, H., Fuzzi, S., Gehrig, R., Hansson, H. C., Harrison, R. M., Herrmann, H., Hitzenberger, R., Hüglin, C., Jones, A. M., Kasper-Giebl, A., Kiss, G., Kousa, A., Kuhlbusch, T. A. J., Löschau, G., Maenhaut, W., Molnar, A., Moreno,T., Pekkanen, J., Perrino, C., Pitz, M., Puxbaum, H., Querol, X., Rodriguez, S., Salma, I., Schwarz, J., Smolik, J., Schneider, J., Spindler, G., ten Brink, H., Tursic, J., Viana, M., Wiedensohler, A., and Raes, F.: A European aerosol phenomenology e 3: Physical and chemical characteristics of particulate matter from 60 rural, urban, and kerbside sites across Europe, Atmos. Environ., 44, 1308-1320, 2010.

Schaap, M. and Denier van der Gon, H. A. C.: On the variability of Black Smoke and carbonaceous aerosols in the Netherlands, Atmos. Environ., 41, 5908-5920, 2007.

Schaap, M., van Loon, M., ten Brink, H. M., Dentener, F. J., and Builtjes, P. J. H.: Secondary inorganic aerosol simulations for Europe with special attention to nitrate, Atmos. Chem. Phys., 4, 857-874, doi:10.5194/acp-4-857-2004, 2004.

Schaap, M. Timmermans, R. M. A., Roemer, M., Boersen, G. A. C., Builtjes, P. J. H., Sauter, F. J., Velders, G. J. M., and Beck, J. P.: The LOTOS-EUROS model: Descritpion, validation and latest developments, Int. J. Environ. Poll., 32, 270-290, 2008.

Schaap, M., Manders, A. A. M., Hendriks, E. C. J., Cnossen, J. M., Segers, A. J., Denier van der Gon, H. A. C., Jozwicka, M., Sauter, F. J., Velders, G. J. M., Matthijsen, J., and Builtjes, P. J. H.: Regional Modelling of Particulate Matter for the Netherlands, PBL report 500099008, Bilthoven, The Netherlands, http://www.rivm.nl/bibliotheek/rapporten/500099008.pdf (last access: 31 May 2013), 2009.

Schaap, M., Otjes, R. P., and Weijers, E. P.: Illustrating the benefit of using hourly monitoring data on secondary inorganic aerosol and its precursors for model evaluation, Atmos. Chem. Phys., 11, 11041-11053, doi:10.5194/acp-11-11041-2011, 2011.

Schaap, M., Kranenburg, R., Segers, A. J., Huibregtse, J. N., and Hendriks, C.: Development of a source apportionment module in LOTOS-EUROS, TNO Report TNO-060-UT-2012-00161, 2012.

Simpson, D., Fagerli, H., Jonson, J. E., Tsyro, S., Wind, P., and Tuovinen, J.-P.: Transboundary Acidification, Eutrophication and Ground Level Ozone in Europe, Part 1: Unified EMEP Model Description, EMEP Report 1/2003, Norwegian Meteorological Institute, Oslo, Norway, 2003.

Solazzo, E., Bianconi, R., Vautard, R., Wyat Appel, K., Moran, M. D., Hogrefe, C., Bessagnet, B., Brandt, J., Christensen, J. H., Chemel, C., Coll, I., Denier van der Gon, H. A. C., Ferreira, J., Forkel, R., Francis, X. V., Grell, G., Grossi, P., Hansen,
A. B., Jericevic, A., Kraljevic, L., Miranda, A. I., Nopmongcol, U., Pirovano, G., Prank, M., Riccio, A., Sartelet, K. N., Schaap, M., Silver, J. D., Sokhi, R. S., Vira, J., Werhahn, J., Wolke, R., Yarwood, G., Zhang, J., Rao, S. T., and Galmarini, S.: Model evalution and ensemble modelling of surface-level ozone in Europe and North America in the context of AQMEII, Atmos. Environ., 53, 60-74, 2012a.

Solazzo, E., Bianconi, Pirovano, G., Matthias, V., Vautard, R., Moran, M. D., Wyat Appel, K., Bessagnet, B., Brandt, J., Christensen, J. H., Chemel, C., Coll, I., Ferreira, J., Forkel, R., Francis, X. V., Grell, G., Grossi, P., Hansen, A. B., Miranda, A. I., Nopmongcol, U., Prank, M., Sartelet, K. N., Schaap, M., Silver, J. D., Sokhi, R. S., Vira, J., Werhahn, J., Wolke, R., Yarwood, G., Zhang, J., Rao, S. T., and Galmarini, S.: Operation model evaluation for particulate matter in Europe and North America in the context of AQMEII. Atmos. Environ., 53, 75-92, $2012 \mathrm{~b}$.

Steinbrecher, R., Smiatek, G., Köble, R., Seufert, G., Theloke, J., Hauff, K., Ciccioli, P., Vautard, R., and Curci, G.: Intra- and inter-annual variability of VOC emissions from natural and seminatural vegetation in Europe and neighbouring countries. Atmos. Environ., 43, 1380-1391, http://dx.doi.org/10.1016/j.atmosenv. 2008.09.072doi:10.1016/j.atmosenv.2008.09.072, 2009.

Stern, R., Builtjes, P., Schaap, M., Timmermans, R., Vautard, R., Hodzic, A., Memmesheimer, M., Feldmann, H., Renner, E., Wolke, R., and Kerschbaumer, A.: A model inter-comparison study focussing on episodes with elevated $\mathrm{PM}_{10}$ concentrations, Atmos. Environ., 42, 4567-4588, 2008.

Ten Brink, H. M., Kruisz, C., Kos, G. P. A., and Berner, A.: Composition/size of the light scattering aerosol in the Netherlands, Atmos. Environ., 31, 3955-3962, 1997.

Tsyro, S. G.: To what extent can aerosol water explain the discrepancy between model calculated and gravimetric $\mathrm{PM}_{10}$ and $\mathrm{PM}_{2.5}$ ?, Atmos. Chem. Phys., 5, 515-532, doi:10.5194/acp-5515-2005, 2005.

Van Loon, M., Vautard, R., Schaap, M., Bergström, R., Bessagnet, B., Brandt, J., Builtjes, P. J. H., Christensen, J., Cuvelier, K., Jonson, J. E., Krol, M., Langner, J., Roberts, P., Rouil, L., Stern, R., Tarrasón, L., Thunis, P., Vignati, E., White, L., and Wind, P.: Evaluation of long-term ozone simulations from seven regional air quality models and their ensemble, Atmos. Environ., 41, 2083-2097, 2007.

Van Zanten, M. C., Sauter, F. J., Wichink Kruit, R. J., Van Jaarsveld, J. A., and Van Pul, W. A. J.: Description of the DEPAC module: Dry deposition modelling with DEPAC_GCN2010, RIVM report 680180001/2010, Bilthoven, The Netherlands, 74 pp., 2010.

Viana, M., Amata, F., Alastuey, A., Querol, X., Moreno, T., Dos Santos, S. G., Herce, M. D., and Fernandez-Patier, R.: Chemical tracers of particulate emissions from commercial shipping, Environ. Sci. Technol., 43, 7472-7477, 2009.

Wagstrom, K. M., Pandis, S. N., Yarwood, G., Wilson, G. M., and Morris, R. E.: Development and application of a computationally efficient particulate matter apportionment algorithm in a three dimensional chemical transport model, Atmos. Environ., 42, 56505659, 2008.

Walcek, C. J. and Aleksic, N. M.: A simple but accurate mass conservative peak-preserving, Mixing ratio bounded advection algorithm with fortran code, Atmos. Environ., 32, 3863-3880, 1998.

Wang, Z. S., Chien, C.-J., and Tonnesen, G. S.: Development of a tagged species source apportionment algorithm to character- 
ize three-dimensional transport and transformation of precursors and secondary pollutants, J. Geophys. Res., 114, D21206, doi:10.1029/2008JD010846, 2009.

Weijers, E. P., Schaap, M., Nguyen, L., Matthijsen, J., Denier van der Gon, H. A. C., ten Brink, H. M., and Hoogerbrugge, R.: Anthropogenic and natural constituents in particulate matter in the Netherlands, Atmos. Chem. Phys., 11, 2281-2294, doi:10.5194/acp-11-2281-2011, 2011

Whitten, G., Hogo, H., and Killus, J.: The Carbon Bond Mechanism for photochemical smog, Environ. Sci. Technol., 14, 1469014700, 1980.
Wichink Kruit, R. J., Schaap, M., Sauter, F. J., van Zanten, M. C., and van Pul, W. A. J.: Modeling the distribution of ammonia across Europe including bi-directional surface-atmosphere exchange, Biogeosciences, 9, 5261-5277, doi:10.5194/bg-9-52612012, 2012.

Yarwood, G., Morris, R. E., and Wilson, G. M.: Particulate Matter Source Apportionment Technology (PSAT) in the CAMX photochemical grid model, http://www.camx.com/publ/pdfs/Yarwood_ ITM_paper.pdf (last access: 31 May 2013), 2004.

Ying, Q. and Kleeman, M. J.: Source contributions to the regional distribution of secondary particulate matter in California, Atmos. Environ., 40, 736-752, 2006. 